\title{
Potential Management Strategies of Tourism Villages in Malang Regency Towards the Development of Village-Owned Enterprises (BUMDes) in Malang Regency
}

\author{
Mohamad Nur Singgih \\ Universitas Merdeka Malang \\ Priyo Sudibyo \\ Universitas Merdeka Malang \\ Suatmo Pantja Putra \\ Universitas Merdeka Malang
}

\begin{abstract}
The purpose of this research is to find out and analyze the management of tourism village potential towards the development of BUMDes in Malang Regency. The research approach uses quantitative descriptive by using data collection techniques through interviews with informants who are considered to have the potential to provide information about the BUMDes management process. The research uses sample of 195 respondents. The method of analyzing research data uses structural equation modeling (SEM). The results showed the influence of natural attractions, accessibility support, several tourist facilities, infrastructure and institutions influence the development of BUMDes in Malang Regency. Perception of BUMDes success is measured by increasing the income of the village community.
\end{abstract}

Keywords: Management, Development, Tourism, Attractions

DOI: $10.7176 / \mathrm{EJBM} / 11-36-05$

Publication date: December $31^{\text {st }} 2019$

\section{INTRODUCTION}

Based on the Law Number 6 of 2014 concerning Villages states that it provides autonomy for villages to manage their own resources and the direction of their own development. In addition, villages are expected to become socially, culturally, economically, even politically independent. The village has autonomy and authority in planning, public services, and finance. Autonomy owned by the village is expected to accelerate the development of villages that aim to improve the quality of human life and poverty reduction through the provision of meeting basic needs, construction of facilities and infrastructure, development of local economic potential, and sustainable the usage of natural resources and the environment by promoting togetherness, kinship, and cooperation. In relation to the effort to improve the welfare of the community through local economic development, the Law No. 14 of 2014 article 87 provides the space for village governments to form VillageOwned Enterprises (BUMDes) in accordance with the needs and potentials of villages which are managed with a family spirit and mutual cooperation to utilize all economic potentials, economic institutions, as well as the potential of natural and human resources in order to improve the welfare of rural communities. The VillageOwned Enterprises (BUMDes) means the village business institutions which are managed by the community and village government in an effort to strengthen the village economy and are formed based on the needs and potential of the village. BUMDes is a pillar of economic activity in the village that has functions not only as a social institution but also a commercial institution. According to Heru (2016) in the context of BUMDes contributions, it is a multi-sector economic unit that is managed by the village government and the community to make the most of the interests of the village community. The establishment of Village-Owned Enterprises aims as a driver of village-level local economic development. The local economic development of the village is based on the needs, potential, capacity of the village, and capital investment from the village government in the form of village finance and wealth with the ultimate goal of improving the economic status of the village community. The basis for the establishment of BUMDes as a locomotive of development in the village is more motivated by the government and village community initiatives based on the cooperative, participatory, and emancipatory principles of the village community. BUMDes is expected to be a driving force for economic activity in the village which also has functions as a social and commercial institution. BUMDes as a social institution favors the interests of the community through its contribution in the provision of social services, while as a commercial institution BUMDes aims to find profits to increase village income. Ihsan (2018) the success of BUMDes was shown by its well-managed business units, community participation and empowerment, village government support, and collaboration with third parties. Malang Regency Government has set 16 villages as tourism villages by indicating that each village must have the potential of natural and cultural attractions which are able 
to attract tourist visits so that it has an impact on increasing people's income. Gumelar (2010:21) tourism village is one of the alternative tourism products that can provide impetus for sustainable rural development and has management principles including: (1) utilizing the facilities and infrastructure of the local community, (2) benefiting the local community, (3) having small scale to facilitate mutual relations with the local community, (4) involving local communities, (5) implementing rural tourism product development. This research survey shows a number of Village-Owned Enterprises (BUMDes) in Malang Regency have success to manage the potential of their village to become a leading tourist village destination which is able to drive the rural economy. One of the BUMDes that has success to manage the tourism village potential is BUMDes Sumber Sejahtera, Pujon Kidul village, Pujon sub-district, Malang regency. This BUMDes has 8 (eight) business units that contribute to moving the economy of Pujon Kidul village. One of the business units that has been successfully managed is the tourist destination of Café Sawah Pujon Kidul. The success of the Pujon Kidul Paddy Café is measured by the ability of the business unit in managing the potential of the tourist village to become an alternative tourism that attracts the interest of tourist visits. The support of tourism potential involves the natural attractions with cool air and attractive natural scenery as well as restaurant or café facilities in the middle of rice fields, easy accessibility, infrastructure, and community participation. They have been able to attract tourists to visit an average of 2000 tourists per day (data sources; visits tourist Pujon Kidul 2019). Pujon Kidul Café Sawah has become a successful management model of tourism village potential for BUMDes development in Malang Regency with an indication of the ability to increase the income of rural communities, reduce unemployment, open up business opportunities for the community, and increase village original income.

The problem in this study is the development of BUMDes in 16 tourist villages in Malang Regency. This is interesting to be used as a study to find out and analyze the influence of the management of the tourism village potential that consists of potential attractions, infrastructure, facilities, accessibility and institutional support of the village for the development of Village-Owned Enterprises (BUMDes). The purpose of this study is to determine and analyze the influence of the potential management of tourism villages on the development of BUMDes in Malang Regency. The results of this study are expected to be a model for developing BUMDes in managing the potential of tourism villages in Malang Regency.

\section{LITERATURE REVIEW}

Tourism is a phenomenon that arises because of interactions between tourists, service providers / the tourism industry, and the government in providing facilities and services that support tourism activities (Ismayanti, 2010). The various interactions form a system that is connected to one another. According to Gunn and Var (2002), the tourism system is basically formed through a linear supply and demand approach. The inventory component is a component that consists of attractions, accommodation, transportation, services, information and promotion. On the other hand, the demand component is all things related to the tourism demand originating from the tourists. In this case, the demand component acts as a market, which is to determine what tourists want, tourists' needs and their ability to pay. Although the tourism system is described through a closed system, but this model can be used to analyze important components in providing attractiveness to a tourist destination (Fajriasanti, 2010). Gunn and Var (2002) suggest that there are at least nine external factors in the tourism system, namely: (a) natural resources; (b) culture; (c) entrepreneurship; (d) finance and financing; (e) labor; (f) competition; (g) community; (h) government policies include policies issued by the government, both at the central, regional and local levels which can affect the level of tourism development; and (i) organization / institution.

Figure 1 


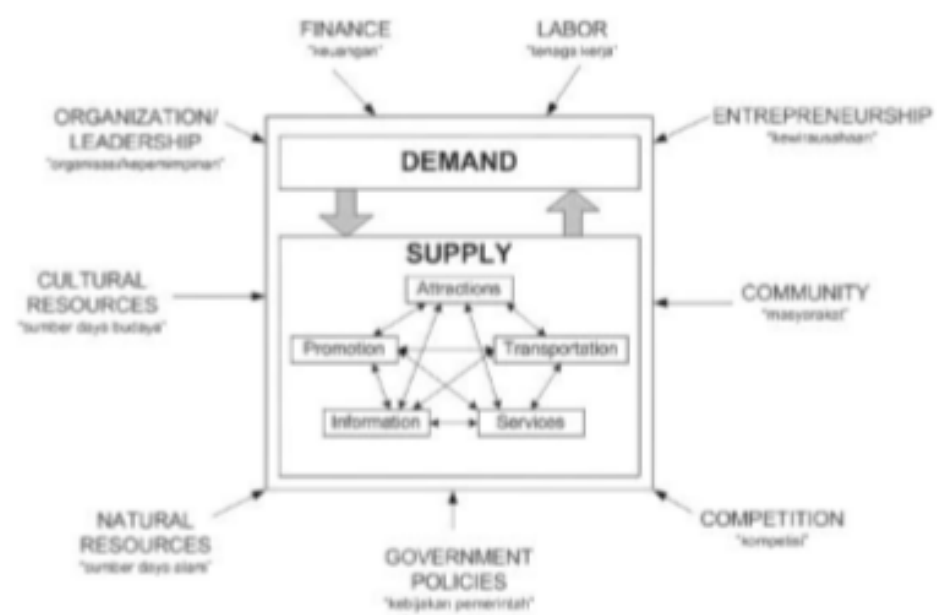

In its development, tourism has several forms, one of which is community-based tourism. The Community Based Tourism (CBT) is a form of tourism that is managed by local communities with an emphasis on environmental, social, and cultural sustainability principles to help tourists to understand and learn the way of life of local communities. CBT aims to build and strengthen organizational capabilities in local communities. This distinguishes CBT from conventional tourism which maximizes profits for investors (mass tourism). The CBT prioritizes refer to the improving community welfare through empowering local communities (Suansri, 2003 and Muallisin, 2007). According to Okazaki (2008), the concept of CBT has several advantages including: (a) the existence of local resources owned and managed by local communities. These local resources are not only limited to the community, but also include the natural environment, infrastructure, and local culture; (b) having local responsibility means the management carried out by the local community so that the community can be more responsible; (c) community involvement in CBT that can protect the natural environment and local culture; (d) allows for a different tourism management system between regions. This is adjusted to the social and economic conditions of the community, so that the community can maintain and manage their assets in accordance with local wisdom. The establishment of a tourist village is one form of CBT implementation. Through the development of tourism villages, welfare distribution is expected to occur. This is in accordance with the concept of sustainable tourism development. In addition, the existence of a tourism village is able to preserve the cultural preservation of rural communities through the involvement of the community as the actor of the tourism activities in their village (Susyanti, 2013). Furthermore, Damanik (2009), argues that the development of tourism villages is basically based on the potential of rural communities themselves. Thus, through the development of tourism villages, it is expected to be able to encourage the growth of various community-based economic sectors such as the handicraft industry, service-trade industry, and others. This kind of thing is expected to be a factor of attraction for tourists to visit the tourist villages.

No

Source of Tourism Village Component

Study of Tourism Village Component Theory

Theory

Gumelar

Prasiasa

(2012)
1. Uniqueness, authenticity, characteristic

2. Its location is adjacent to extraordinary natural areas

3. Relating to cultured groups or communities that essentially attract the interest of visitors

4. Has the opportunity to develop both in terms of basic infrastructure and other facilities

1. Has the potential for tourism, arts, and culture typical of the local area.

2. The location of the village is included in the scope of the area of tourism development or at least is in the corridors and routes of tour packages already sold.

3. Preference will be made on the management, trainers and actors in tourism, arts and culture.

4. Accessibility and infrastructure that support the Tourism Village program.

5. Guaranteed of security, order and cleanliness..

Gumelar (2010: 21) argues that the tourism village is one of the alternative tourism products that can provide encouragement for sustainable rural development and has management principles, including: (1) utilizing the facilities and infrastructure of the local community, (2) benefiting the local community, (3) having 
small scale to facilitate mutual relations with the local community, (4) involving the local community, (5) implementing rural tourism product development, and some underlying criteria such as:

a. Provision of facilities and infrastructure owned by local communities which usually encourages community participation and guarantees access to physical resources. This is a stepping stone for the development of a tourist village. Furthermore, this can encourage increased income from the agricultural sector and other economic activities.

b. Local residents have an effective role in the process of making decisions about the form of tourism that utilizes environmental areas. Local residents receive an appropriate division of income from tourism activities.

c. Encouraging the development of local community entrepreneurship.

Management of tourism village potentials must be able to increase the competitiveness of tourism villages to attract tourist visits. (Hassan, 2000: 239) "Competitiveness concerns the ability of destinations to create and integrate value-added products that maintain their resources while maintaining market positions relative to competitors". Dwyer and Kim (2003) destination competitiveness is "the ability of a destination to deliver goods and services that perform better than other destinations on those aspects of the tourism experience considered being important by tourists". Ritchie and Crouch (2003) describe competitiveness as the ability to increase tourism spending by attracting more visitors while giving them a satisfying and memorable experience. On the other hand it is also to do it in a profitable way, while increasing the welfare of the destination population and preserving the destination's natural capital for future generations.

In the context of tourism village development, the role of Village-Owned Enterprises (BUMDes) is very strategic in managing the potential of tourism villages to become attractive tourist destinations for tourists. The Village-Owned Enterprises (BUMDes) is a village business institutions which are managed by the community and village government in an effort to strengthen the village economy. Furthermore, The Village-Owned Enterprises (BUMDes) is formed based on the needs and potential of the village. BUMDes is a pillar of economic activity in the village that has functions as a social institution and a commercial institution.

\begin{tabular}{|l|l|}
\hline Researcher & Research Result \\
\hline $\begin{array}{l}\text { Pertiwi } \\
\text { (2017) }\end{array}$ & $\begin{array}{l}\text { BUMDes capacity in managing tourism potential in the village of Ponggok has not been able to } \\
\text { provide adequate tourism infrastructure }\end{array}$ \\
\hline Yusuf (2016) & $\begin{array}{l}\text { The development of an Independent Village through BUMDes has been able to move the rural } \\
\text { economy }\end{array}$ \\
\hline
\end{tabular}

\section{RESEARCH METHODS}

This study uses a quantitative approach that aims to explain the phenomena that exist by using numbers to interpret research results. Data collection was carried out by questionnaire, interview and focus group discussion methods as well as documentation. The sampling technique uses purposive sampling to get respondents who are competent or influential in achieving the goals obtained in the study. The number of samples in this study were 195 respondents.

Research variables and indicators to measure the Potential Management of Tourism Village and Bumdes Development

\begin{tabular}{|c|c|c|}
\hline No & Variable & Indicator \\
\hline 1 & $\begin{array}{l}\text { Development of } \\
\text { Village-Owned } \\
\text { Enterprises (BUMDes) }\end{array}$ & $\begin{array}{l}\text { 1. BUMdes is able to increase the income of rural communities } \\
\text { 2. BUMdes is able to create business opportunities in rural communities } \\
\text { 3. BUMDes is able to absorb labor in the village } \\
\text { 4. BUMDes is able to increase Village Original Income } \\
\text { 5. BUMDes is able to reduce poverty in the village } \\
\text { 6. BUMdes is able to improve environmental sustainability in the village }\end{array}$ \\
\hline 2 & $\begin{array}{l}\text { Potential } \\
\text { Attractions }\end{array}$ & $\begin{array}{l}\text { 1. The village has natural potential which can be developed into a village tourist } \\
\text { attraction } \\
\text { 2. The village has cultural potential which can be developed into a village tourist } \\
\text { attraction } \\
\text { 3. The village has other resources which are unique to the development of artificial } \\
\text { tourist attractions } \\
\text { 4. BUMdes has HR who are able to develop village tourist attractions } \\
\text { 5. BUMdes has financial resources to develop village tourism attractions } \\
\text { 6. BUMDes has the ability to establish channeling or partnerships with other } \\
\text { 7. BUMDes has adequate planning in developing village tourist attraction }\end{array}$ \\
\hline 3. & Infrastructure & $\begin{array}{l}\text { 1. There is a communication network to support the development of tourist villages } \\
\text { 2. The availability of electricity to support the development of rural tourism } \\
\text { facilities } \\
\text { 3. The adequate road conditions to support accessibility for tourist villages }\end{array}$ \\
\hline
\end{tabular}




\begin{tabular}{|c|c|c|}
\hline No & Variable & Indicator \\
\hline & & $\begin{array}{l}\text { 4. There is an adequate source of clean water to support the development of a } \\
\text { tourism village } \\
\text { 5. The waste management system which supports the development of tourist } \\
\text { villages }\end{array}$ \\
\hline 4 & Tourist Facilities & $\begin{array}{l}\text { 1. There is a tourist cottage (home stay) as a means for tourists to stay } \\
\text { 2. The sufficient place or parking area to accommodate tourist vehicles } \\
\text { 3. Typical souvenirs for tourists } \\
\text { 4. There are toilets for tourists } \\
\text { 5. There are adequate religious facilities (mosque) for tourists } \\
\text { 6. There are stalls or markets for tourist shopping } \\
\text { 7. Having a dining facility (restaurant or stall) for tourists } \\
\text { 8. There are Small and Medium Enterprises which support the development of } \\
\text { tourist villages }\end{array}$ \\
\hline 5 & Accessibility & $\begin{array}{l}\text { 1. The location of the tourist village is easily reached by public transportation } \\
\text { 2. The road to the village can be easily traversed by private vehicles or public } \\
\text { transportation } \\
\text { 3. The access of the tourist village is closed to the city center } \\
\text { 4. The access of the tourist village can be reached easily through the terminal, } \\
\text { airport and station } \\
\text { 5. There is a transportation mode available to the tourist village }\end{array}$ \\
\hline 6 & Institutional & $\begin{array}{l}\text { 1. The support in the form of policies and funds from the Regency government for } \\
\text { the development of tourism villages } \\
\text { 2. The support in the form of policies and funds from the Village government for } \\
\text { the development of tourism villages } \\
\text { 3. The support from the village institutions (BPD, LPMD, POKDARWIS, PKK) for } \\
\text { the development of tourism villages } \\
\text { 4. The support from community organizations for the development of tourism } \\
\text { villages. }\end{array}$ \\
\hline
\end{tabular}

The data analysis methods to analyze the influence of the potential of tourism village management on BUMDes development uses structural equation modeling (SEM).

\section{RESULTS AND DISCUSSION}

a. Description of the BUMDES Development variable (Y)

The frequency distribution of BUMDES development (Y) is as follows:

Table 1

BUMDES Development Variable Frequency Distribution (Y)

\begin{tabular}{|c|c|c|c|c|c|c|c|c|c|c|c|}
\hline \multirow{3}{*}{ Item } & \multicolumn{10}{|c|}{ Answer Score } & \multirow{3}{*}{ average } \\
\hline & \multicolumn{2}{|c|}{$\begin{array}{l}\text { Strongly } \\
\text { agree }\end{array}$} & \multicolumn{2}{|c|}{ Agree } & \multicolumn{2}{|c|}{ Neutral } & \multicolumn{2}{|c|}{ Disagree } & \multicolumn{2}{|c|}{$\begin{array}{l}\text { Strongly } \\
\text { disagree }\end{array}$} & \\
\hline & $\mathrm{F}$ & $\%$ & $\mathrm{~F}$ & $\%$ & $\mathrm{~F}$ & $\%$ & $\mathrm{~F}$ & $\%$ & $\mathrm{~F}$ & $\%$ & \\
\hline $\begin{array}{l}\text { BUMdes is able to increase the income of } \\
\text { rural communities }\end{array}$ & 60 & 30,8 & 97 & 49,7 & 32 & 16,4 & 5 & 2,6 & 1 & 0,5 & 4,08 \\
\hline $\begin{array}{l}\text { BUMdes is able to create business } \\
\text { opportunities in rural communities }\end{array}$ & 56 & 28,7 & 93 & 47,7 & 37 & 19,0 & 9 & 4,6 & 0 & 0,0 & 4,01 \\
\hline $\begin{array}{l}\text { BUMdes is able to absorb the workforce in } \\
\text { the village }\end{array}$ & 55 & 28,2 & 96 & 49,2 & 34 & 17,4 & 8 & 4,1 & 2 & 1,0 & 3,99 \\
\hline $\begin{array}{l}\text { BUMdes is able to increase Village } \\
\text { Original Income }\end{array}$ & 62 & 31,8 & 93 & 47,7 & 33 & 16,9 & 6 & 3,1 & 1 & 0,5 & 4,07 \\
\hline $\begin{array}{l}\text { BUMdes is able to reduce poverty in the } \\
\text { village }\end{array}$ & 54 & 27,7 & 82 & 42,1 & 47 & 24,1 & 11 & 5,6 & 1 & 0,5 & 3,91 \\
\hline $\begin{array}{l}\text { BUMdes is able to improve environmental } \\
\text { sustainability in the village }\end{array}$ & 58 & 29,7 & 93 & 47,7 & 38 & 19,5 & 5 & 2,6 & 1 & 0,5 & 4,04 \\
\hline $\begin{aligned} & \text { The average } \\
&\end{aligned}$ & BUI & ES De & elop & ient sc & re ( & & & & & & 4,02 \\
\hline
\end{tabular}

Source: Primary data processed, 2019.

Overall, the average BUMDES development variable is 4.02 , this shows that respondents tend to strongly agree that BUMdes is not only able to increase the income of rural communities, create business opportunities in rural communities, absorb labor in the village, increase Village Original Income, reduce poverty in the village, but also improve environmental sustainability in the village.

b. The description of the Attraction variable (X1)

The frequency distribution of attractions (X1) is presented in the following table. 
Table 2 The Attraction Variable Frequency Distribution (X1)

\begin{tabular}{|c|c|c|c|c|c|c|c|c|c|c|c|}
\hline \multirow{3}{*}{ Item } & \multicolumn{10}{|c|}{ Answer Score } & \multirow{3}{*}{ Average } \\
\hline & \multicolumn{2}{|c|}{$\begin{array}{l}\text { Strongly } \\
\text { agree }\end{array}$} & \multicolumn{2}{|c|}{ Agree } & \multicolumn{2}{|c|}{ Neutral } & \multicolumn{2}{|c|}{ Disagree } & \multicolumn{2}{|c|}{$\begin{array}{l}\text { Strongly } \\
\text { disagree }\end{array}$} & \\
\hline & $\mathrm{F}$ & $\%$ & $\mathrm{~F}$ & $\%$ & $\mathrm{~F}$ & $\%$ & $\mathrm{~F}$ & $\%$ & $\mathrm{~F}$ & $\%$ & \\
\hline $\begin{array}{l}\text { The village has natural potential that can be } \\
\text { developed into a village tourist attraction }\end{array}$ & 90 & 46,2 & 74 & 37,9 & 24 & 12,3 & 7 & 3,6 & 0 & 0,0 & 4,27 \\
\hline $\begin{array}{l}\text { The village has cultural potential that can be } \\
\text { developed into a village tourist attraction }\end{array}$ & 69 & 35,4 & 93 & 47,7 & 25 & 12,8 & 8 & 4,1 & 0 & 0,0 & 4,14 \\
\hline $\begin{array}{l}\text { The village has other resources that are } \\
\text { unique to support the development of } \\
\text { artificial tourist attractions }\end{array}$ & 53 & 27,2 & 89 & 45,6 & 47 & 24,1 & 6 & 3,1 & 0 & 0,0 & 3,97 \\
\hline $\begin{array}{l}\text { BUMdes has HR who are able to develop } \\
\text { village tourist attractions }\end{array}$ & 48 & 24,6 & 94 & 48,2 & 44 & 22,6 & 8 & 4,1 & 1 & 0,5 & 3,92 \\
\hline $\begin{array}{l}\text { BUMdes has financial resources to develop } \\
\text { village tourist attractions }\end{array}$ & 41 & 21,0 & 85 & 43,6 & 58 & 29,7 & 11 & 5,6 & 0 & 0,0 & 3,80 \\
\hline $\begin{array}{l}\text { BUMDes has the ability to build } \\
\text { partnerships with other parties in developing } \\
\text { village tourism attractions }\end{array}$ & 32 & 16,4 & 102 & 52,3 & 54 & 27,7 & 6 & 3,1 & 0 & 0,0 & 3,84 \\
\hline $\begin{array}{l}\text { BUMDes has adequate planning in } \\
\text { developing village tourist attractions }\end{array}$ & 34 & 17,4 & 99 & 50,8 & 55 & 28,2 & 6 & 3,1 & 1 & 0,5 & 3,82 \\
\hline The $A$ & $\pi_{8}$ & ttract & $\mathrm{s} \mathrm{sc}$ & (X1) & & & & & & & 3,96 \\
\hline
\end{tabular}

Source: Primary data processed, 2019.

Overall, the average Attraction variable is 3.96, this shows that respondents tend to agree that the village has natural and cultural potential that can be developed into a village tourist attraction, the village has other resources that have specificities to develop artificial tourist attraction, BUMdes has HR and financial resources which are able to develop village tourist attractions, BUMDes has the ability to build partnerships with other parties in developing village tourist attractions and BUMDes has adequate planning in developing village tourist attractions.

c. The Description of the Infrastructure variable (X2)

The frequency distribution of infrastructure (X2) is presented in the following table.

Table 3 Infrastructure Variable Frequency Distribution (X2)

\begin{tabular}{|c|c|c|c|c|c|c|c|c|c|c|c|}
\hline \multirow{3}{*}{ Item } & \multicolumn{10}{|c|}{ Answer Score } & \multirow{3}{*}{ Average } \\
\hline & \multicolumn{2}{|c|}{$\begin{array}{c}\text { Strongly } \\
\text { Agree }\end{array}$} & \multicolumn{2}{|c|}{ Agree } & \multicolumn{2}{|c|}{ Neutral } & \multicolumn{2}{|c|}{ Disagree } & \multicolumn{2}{|c|}{$\begin{array}{l}\text { Strongly } \\
\text { Disagree }\end{array}$} & \\
\hline & $\mathrm{F}$ & $\%$ & $\mathrm{~F}$ & $\%$ & $\mathrm{~F}$ & $\%$ & $\mathrm{~F}$ & $\%$ & $\mathrm{~F}$ & $\%$ & \\
\hline $\begin{array}{l}\text { The communication networks are } \\
\text { available to support the } \\
\text { development of rural tourism }\end{array}$ & 41 & 21,0 & 78 & 40,0 & 57 & 29,2 & 11 & 5,6 & 8 & 4,1 & 3,68 \\
\hline $\begin{array}{l}\text { The electricity is available to } \\
\text { support the development of rural } \\
\text { tourism facilities }\end{array}$ & 59 & 30,3 & 85 & 43,6 & 39 & 20,0 & 11 & 5,6 & 1 & 0,5 & 3,97 \\
\hline $\begin{array}{l}\text { The adequate road conditions to } \\
\text { support accessibility for tourist } \\
\text { villages }\end{array}$ & 56 & 28,7 & 78 & 40,0 & 43 & 22,1 & 16 & 8,2 & 2 & 1,0 & 3,87 \\
\hline $\begin{array}{l}\text { There is an adequate source of } \\
\text { clean water to support the } \\
\text { development of a tourism village }\end{array}$ & 66 & 33,8 & 90 & 46,2 & 34 & 17,4 & 5 & 2,6 & 0 & 0,0 & 4,11 \\
\hline $\begin{array}{l}\text { The waste management system } \\
\text { that supports the development of a } \\
\text { tourism village }\end{array}$ & 50 & 25,6 & 74 & 37,9 & 47 & 24,1 & 20 & 10,3 & 4 & 2,1 & 3,75 \\
\hline & $\mathrm{a}-\mathrm{ra}$ & skor 1 & $40 \mathrm{~s}$ & ruktur & $(\mathrm{X} 2$ & & & & & & 3,88 \\
\hline
\end{tabular}

Source: Primary data processed, 2019.

Overall the average infrastructure variable is 3.88 , this shows that respondents tend to agree that there are a communication network available to support the development of rural tourism, an available electricity to support 
the development of rural tourism facilities, an adequate road conditions to support accessibility for tourists to the village tourism, an adequate source of clean water to support the development of a tourism village and a waste management system that supports the development of a tourism village.

d. The Description of the variable Tourist Facilities (X3)

The frequency distribution of tourist facilities (X3) is presented in the following table. Table 4 Variable Frequency Distribution of Tourist Facilities (X3)

\begin{tabular}{|c|c|c|c|c|c|c|c|c|c|c|c|}
\hline \multirow{3}{*}{ Item } & \multicolumn{10}{|c|}{ Answer Score } & \multirow{3}{*}{ Average } \\
\hline & \multicolumn{2}{|c|}{$\begin{array}{l}\text { Strongly } \\
\text { Agree }\end{array}$} & \multicolumn{2}{|c|}{ Agree } & \multicolumn{2}{|c|}{ Nuetral } & \multicolumn{2}{|c|}{ Disagree } & \multicolumn{2}{|c|}{$\begin{array}{l}\text { Strongly } \\
\text { disagree }\end{array}$} & \\
\hline & F & $\%$ & $\mathrm{~F}$ & $\%$ & $\mathrm{~F}$ & $\%$ & $\mathrm{~F}$ & $\%$ & F & $\%$ & \\
\hline $\begin{array}{l}\text { There is a tourist cottage (home } \\
\text { stay) as a means for tourists to stay }\end{array}$ & 38 & 19,5 & 81 & 41,5 & 35 & 17,9 & 32 & 16,4 & 9 & 4,6 & 3,55 \\
\hline $\begin{array}{l}\text { The sufficient space or parking } \\
\text { area to accommodate tourist } \\
\text { vehicles }\end{array}$ & 52 & 26,7 & 87 & 44,6 & 44 & 22,6 & 10 & 5,1 & 2 & 1,0 & 3,91 \\
\hline Typical souvenirs for tourists & 31 & 15,9 & 75 & 38,5 & 54 & 27,7 & 29 & 14,9 & 6 & 3,1 & 3,49 \\
\hline There are toilets for tourists & 66 & 33,8 & 71 & 36,4 & 46 & 23,6 & 10 & 5,1 & 2 & 1,0 & 3,97 \\
\hline $\begin{array}{l}\text { There are adequate religious } \\
\text { facilities (prayer rooms, mosque) } \\
\text { for tourists }\end{array}$ & 78 & 40,0 & 71 & 36,4 & 37 & 19,0 & 8 & 4,1 & 1 & 0,5 & 4,11 \\
\hline $\begin{array}{l}\text { There are stalls or markets for } \\
\text { tourist shopping }\end{array}$ & 57 & 29,2 & 76 & 39,0 & 31 & 15,9 & 17 & 8,7 & 14 & 7,2 & 3,74 \\
\hline $\begin{array}{l}\text { Have a dining facility (restaurant or } \\
\text { stall) for tourists }\end{array}$ & 43 & 22,1 & 86 & 44,1 & 39 & 20,0 & 15 & 7,7 & 12 & 6,2 & 3,68 \\
\hline $\begin{array}{l}\text { There are Small and Medium } \\
\text { Enterprises that support the } \\
\text { development of tourist villages }\end{array}$ & 39 & 20,0 & 84 & 43,1 & 44 & 22,6 & 23 & 11,8 & 5 & 2,6 & 3,66 \\
\hline The $A$ & & Touri & Fac & $\mathrm{y} \mathrm{sec}$ & & & & & & & 3,76 \\
\hline
\end{tabular}

Source: Primary data processed, 2019.

Overall the average tourist facilities variable is 3.76 , this shows that respondents tend to agree that tourist attractions provide a tourist cottage (home stay) as a means to stay tourists, places or parking areas that are sufficient to accommodate tourist vehicles, typical souvenirs for tourists, toilets for tourists, there are adequate religious facilities (prayer rooms, mosques) for tourists, stalls or markets available for tourist shopping, have dining facilities (restaurants or stalls) for tourists, and there are Small and Medium Enterprises that support the development of tourist villages.

e. The Description of the Accessibility variable (X4)

The frequency distribution of accessibility (X4) is presented in the following table. Table 5 Accessibility Variable Frequency Distribution (X4)

\begin{tabular}{|c|c|c|c|c|c|c|c|c|c|c|c|}
\hline \multirow{3}{*}{ Item } & \multicolumn{10}{|c|}{ Answer Score } & \multirow{3}{*}{ Average } \\
\hline & \multicolumn{2}{|c|}{$\begin{array}{l}\text { Strongly } \\
\text { Agree }\end{array}$} & \multicolumn{2}{|c|}{ Agree } & \multicolumn{2}{|c|}{ Neutral } & \multicolumn{2}{|c|}{ Disagree } & \multicolumn{2}{|c|}{$\begin{array}{l}\text { Strongly } \\
\text { Disagree }\end{array}$} & \\
\hline & $\mathrm{F}$ & $\%$ & $F$ & $\%$ & $\mathrm{~F}$ & $\%$ & $\mathrm{~F}$ & $\%$ & $\mathrm{~F}$ & $\%$ & \\
\hline $\begin{array}{l}\text { The location of the tourist village } \\
\text { is easily accessible by public } \\
\text { transportation }\end{array}$ & 64 & 32,8 & 83 & 42,6 & 48 & 24,6 & 0 & 0,0 & 0 & 0,0 & 4,08 \\
\hline $\begin{array}{l}\text { The road to the village can be } \\
\text { easily traversed by private } \\
\text { vehicles or public transportation }\end{array}$ & 52 & 26,7 & 91 & 46,7 & 52 & 26,7 & 0 & 0,0 & 0 & 0,0 & 4,00 \\
\hline $\begin{array}{l}\text { Access tourist village is closed to } \\
\text { the city center }\end{array}$ & 20 & 10,3 & 46 & 23,6 & 55 & 28,2 & 54 & 27,7 & 20 & 10,3 & 2,96 \\
\hline $\begin{array}{l}\text { Access to tourist villages can be } \\
\text { reached easily through the } \\
\text { terminal, airport and station }\end{array}$ & 22 & 11,3 & 23 & 11,8 & 56 & 28,7 & 61 & 31,3 & 33 & 16,9 & 2,69 \\
\hline $\begin{array}{l}\text { Available modes of transportation } \\
\text { leading to the village tourism }\end{array}$ & 18 & 9,2 & 15 & 7,7 & 47 & 24,1 & 84 & 43,1 & 31 & 15,9 & 2,51 \\
\hline The & iver & Acc & sibi & $y \operatorname{sco}$ & $\left(\mathrm{X}^{4}\right.$ & & & & & & 3,25 \\
\hline
\end{tabular}

Source: Primary data processed, 2019. 
Overall the average accessibility variable is 3.25 , this shows that respondents tend to agree that the location of the tourist village is easily accessible by public transportation, the road to the village can be easily passed by private vehicles or public transportation, the access of the tourist village is close to downtown, access to tourist villages can be reached easily through terminals, airports and stations and there are modes of transportation that lead to the tourist village.

f. Description of the Institutional variable (X5)

The institutional frequency distribution (X5) is presented in the following table.

Table 6 Institutional Variable Frequency Distribution (X5)

\begin{tabular}{|c|c|c|c|c|c|c|c|c|c|c|c|}
\hline \multirow{3}{*}{ Item } & \multicolumn{10}{|c|}{ Answer Score } & \multirow{3}{*}{ Average } \\
\hline & \multicolumn{2}{|c|}{$\begin{array}{l}\text { Strongly } \\
\text { Agree }\end{array}$} & \multicolumn{2}{|c|}{ Agree } & \multicolumn{2}{|c|}{ Neutral } & \multicolumn{2}{|c|}{ Disagree } & \multicolumn{2}{|c|}{$\begin{array}{l}\text { Strongly } \\
\text { Disagree }\end{array}$} & \\
\hline & $\mathrm{F}$ & $\%$ & $\mathrm{~F}$ & $\%$ & $\mathrm{~F}$ & $\%$ & $\mathrm{~F}$ & $\%$ & F & $\%$ & \\
\hline $\begin{array}{l}\text { The support in the form of policies } \\
\text { and funds from the Regency } \\
\text { government for the development of } \\
\text { rural tourism }\end{array}$ & 46 & 23,6 & 68 & 34,9 & 52 & 26,7 & 12 & 6,2 & 17 & 8,7 & 3,58 \\
\hline $\begin{array}{l}\text { The support in the form of policies } \\
\text { and funds from the village } \\
\text { government for the development of } \\
\text { rural tourism }\end{array}$ & 54 & 27,7 & 69 & 35,4 & 56 & 28,7 & 9 & 4,6 & 7 & 3,6 & 3,79 \\
\hline $\begin{array}{l}\text { The support from village institutions } \\
(B P D, L P M D, P O K D A R W I S, P K K) \\
\text { for the development of rural tourism }\end{array}$ & 59 & 30,3 & 76 & 39,0 & 52 & 26,7 & 7 & 3,6 & 1 & 0,5 & 3,95 \\
\hline $\begin{array}{l}\text { The support from community } \\
\text { organizations for the development of } \\
\text { rural tourism }\end{array}$ & 61 & 31,3 & 73 & 37,4 & 51 & 26,2 & 8 & 4,1 & 2 & 1,0 & 3,94 \\
\hline (2) & & nst & & $\mathrm{Sc}$ & X5) & & & & & & 3,82 \\
\hline
\end{tabular}

Source: Primary data processed, 2019.

Overall the average institutional variable is 3.82 , this shows that respondents tend to agree that the support in the form of policies and funds from the Regency government for the development of tourism villages, the support in the form of policies and funds from the village government for the development of tourism villages, support from village institutions (BPD, LPMD, POKDARWIS, PKK) for the development of tourism villages and the support of community organizations on the development of tourism villages.

g. SEM Analysis Results

This research was conducted by looking at the $p$ value (probability), if the $p$ value is more than or equal to 0.05 , then it is said that there is a significant influence.

Table 7

The Effect of Attraction, Infrastructure, Tourist Facilities, Accessibility and Institutions on BUMDes Development

\begin{tabular}{|l|c|c|c|c|c|}
\hline \multicolumn{1}{|c|}{ Variabel } & Standardized Regression Weight & Estimate & S.E & C.R. & P \\
\hline Attraction) (X1) & 0,439 & 0,651 & 0,16 & 4,065 & 0,000 \\
\hline Infrastructure (X2) & 0,212 & 0,234 & 0,112 & 2,091 & 0,037 \\
\hline Tourist Facilities (X3) & 0,214 & 0,218 & 0,101 & 2,151 & 0,031 \\
\hline Accessibility (X4) & 0,344 & 0,488 & 0,12 & 4,066 & 0,000 \\
\hline Institutions (X5) & 0,164 & 0,137 & 0,067 & 2,062 & 0,039 \\
\hline
\end{tabular}

Source: Primary data processed, 2019.

Table 7 shows that the attraction variable has a critical ratio (CR) value of 4.065 greater than 2 and a pvalue of 0,000 less than 0.05 . In the form of a standardized regression weight attraction coefficient (attractiveness) is 0.439 . These results provide a decision that the variable of attraction (attractiveness) has a positive and significant effect on the development of BUMDes.

The infrastructure variables have a critical ratio (CR) value of 2.091 greater than 2 and a p-value of 0.037 less than 0.05 . In the form of the standardized regression weight infrastructure coefficient is 0.439 . These results provide the decision that the infrastructure variable has a positive and significant effect on the development of BUMDes.

The tourism facility variable has a critical ratio (CR) value of 2.151 greater than 2 and a p-value of 0.031 less than 0.05. In the form of the standardized regression weight coefficient of tourist facilities is 0.214 . These results provide a decision that the tourist facility variable has a positive and significant effect on the development of BUMDes. 
The accessibility variable has a critical ratio (CR) value of 4.066 greater than 2 and a p-value of 0,000 less than 0.05 . In the form of the standardized regression weight accessibility coefficient is 0.344 . These results provide a decision that the accessibility variable has a positive and significant effect on the development of BUMDes.

The institutional variables have a critical ratio (CR) value of 2.062 greater than 2 and a p-value of 0.039 less than 0.05 . In the form of an institutionalized standardized regression weight coefficient of 0.164 . These results provide a decision that the institutional variable has a positive and significant effect on the development of BUMDes.

\section{CONCLUSION}

The management of tourism village potential has a significant influence in the development of Village-Owned Enterprises (BUMDes) in Malang Regency. The management of the tourism village potential is reflected in the management of Attractions (attractiveness) to the development of BUMDes. Attraction plays an important role on the side of tourism products to attract tourist visits to destinations so that it can improve the development of BUMDes, the better the infrastructure owned by tourist attractions can increase the development of BUMDes. Infrastructure refers to all facilities that enable all processes and activities of tourism to run smoothly in order to facilitate tourists to meet their needs. Tourism facilities means that the more complete tourism facilities owned by the tourism village can increase the development of BUMDes. The accessibility is an ease to achieve a goal, which involves not only the comfort, safety, but travel time as well. This is important to note because the higher the accessibility means the easier it is to reach and the higher the level of comfort of tourists to visit. This affects the development of tourists. The support from village institutions (BPD, LPMD, POKDARWIS, PKK) for the development of rural tourism is urgently needed, in addition, the participation of village institutions has influence in BUMDes governance.

\section{REFERENCES}

Coristya, Heru, Suwondo, "The existence of BUMDes as Village Economic Strengthening (Study in Landungsari Village, Bau District, Malang Regency),” Journal of Public Administration (JAP) Vol.I, No.6, hlm. 356

Crouch, G.I. (2010). Destination Competitiveness: An Analysis of Determinant Attributes. Journal of Travel Research, 51(6), 1-19

Crouch, G.I. and Ritchie, J.R.B. (1999). Tourism, Competitiveness and Societal Prosperity. Journal of Business Research, 44(3), 137152.

Damanik, J. (2006). Promotion Strategies Facing the Tourism Crisis and Psychographic Shifts in Tourists. Tourism Journal, 8

Dwyer, L. and Kim, C. (2003). Destination competitiveness: Determinants and Indicators. Current Issues in Tourism, 6(5).

Dwyer, L., Livaic, Z. and Mellor, R. (2003). Competitiveness of Australia as a tourist destination. Journal of Hospitality and Tourism Management, 10(1), 60-78.

Dwyer, L., Mellor, R., Livaic, Z., Edwards, D. and Kim, C. (2004). Attributes of Destination Competitiveness: A Factor Analysis. Tourism Analysis, 9(1-2), 91-101.

Gunn, C. A. \& Var, T. (2002). Tourism Planning: Basics, Concepts, Cases. London: Routledge.

Hassan, S.S. (2000). Determinants of Market Competitiveness in an Environmentally Sustainable Tourism Industry. Journal of Travel Research, 38(3), 239-245

Ismayanti. (2010). Introduction to Tourism. Jakarta: Kompas Gramedi

Muallisin, I. (2007). Model of Community-Based Tourism Development in the City of Yogyakarta. Yogyakarta City Bappeda Research Journal, 2 (Desember), 5-15.

Okazaki, E. (2008). A Community-Based Tourism Model: Its Conception and Use. Journal Of Sustainable Tourism, 16 (5), 511-529.

Inskeep, Edward 1991. Tourism Planning An Integrated Sustainable Development. Van Nostrand Reinhold New York

Prasiasa, Putu Oka. 2012. Community Based Tourism Destinations, Jakarta :Salemba Empat

Sastrayuda, Gumelar S. 2010. Lecture Handout Concept Development and Management Strategy Resort and Leisure. Bandung

Sugiarti, R. 2004. Solutions and Applications for Community-Based Tourism Development Enterprises, Paper presented at the Seminar on Community-Based Tourism Development. 18 Februari 2004. Semarang

Suansri, P. (2003). Community Based Tourism Handbook. Thailand: Rest Project.

Susyanti, D. W. (2013). Village Potentials Through Rural Tourism. Journal of Economics and Business, 12 (1), $33-36$. 
Republic of Indonesian Law No. 10 of 2009, concerning Tourism.

Republic of Indonesia Law No. 6 of 2014, concerning Villages. 